AGORA International Journal of Juridical Sciences, www.juridicaljournal.univagora.ro

ISSN 1843-570X, E-ISSN 2067-7677

No. 4 (2014), pp. 149-156

\title{
OFFENSE - THE ONLY GROUND FOR CRIMINAL LIABILITY L. R. Popoviciu
}

\section{Laura-Roxana Popoviciu}

Law and Economics Faculty, Social Sciences Department

Agora University of Oradea, Oradea, Romania

*Correspondence: Laura-Roxana Popoviciu, Agora University of Oradea,

8 Piaţa Tineretului St., Oradea, Romania

E-mail: lpopoviciu@yahoo.com

\section{Abstract}

This study aims to examine the offence as the only ground for criminal liability. Article 15, paragraph 2 of the Criminal code provides that: "offences are the only grounds for criminal liability", which implies the existence of an act, which is detected by the bodies empowered under the law in the form required by law, and also this principle comes as a guarantee of the person's freedom because, without committing an act provided for by the law as an offense, the criminal liability cannot exist.

The criminal liability is one of the fundamental institutions of the criminal law, together with the institution of the offence and of the sanction, set in the various provisions of the Criminal code.

As shown in the Criminal code, in Title II regarding the offence, there is a close interdependence among the three fundamental institutions. The offence, as a dangerous act prohibited by the criminal rule, attracts, by committing it, the criminal liability, and the criminal liability without a sanction would lack the object. It obliges the person who committed an offence to be held accountable for it in front of the judicial bodies, to bide the sanctions provided for by the law, and to execute the sanction that was applied.

The correlation is also vice-versa, meaning that the sanction, its implementation, cannot be justified only by the existence of the perpetrator's criminal liability, and the criminal liability may not be based only on committing an offence.

The criminal liability is a form of the judicial liability and it represents the consequence of non-complying with the provision of the criminal rule. Indeed, the achievement of the rule of law, in general, and also the rule of the criminal law implies, from all the law's recipients, a conduct according to the provisions of the law, for the normal evolution of the social relations.

\section{Keywords: criminal liability, offence, criminal law sanction, rule of law}

\section{Introduction}

The achievement of the rule of criminal law takes place by complience by the majority of the criminal law's recipients with its provisions, in the conformation relations. For those who don't comply with their conducts with the dispositions of the criminal rule committing forbidden acts, the recuperation of the broken rule of law and the achievement of the rule of law can take place through the coercion in a criminal judicial relation of conflict.

The criminal liability appears, in other words, as the judicial relation of conflict, of coercion, a complex judicial relation with rights and obligations specific for the participant subjects ${ }^{1}$.

On the same line, the criminal liability is defined, in the present criminal doctrine, as "the judicial criminal relation of coercion, that appears as a consequence after committing an offence between the state, on one hand, and the perpetrator, on the other hand, a complex

\footnotetext{
${ }^{1}$ I. Oancea, Criminal law. General part, (Drept penal. Partea generală), Bucharest, Didactic and Pedagogic Publishing House, 1971, p. 419.
} 
relation whose content is formed by the state's law, as a representative of the society, to bring the perpetrator to account, to apply him/her the sanction provided for the committed offence, to coerce the perpetrator to execute it, and also the perpetrator's obligation to account for his/her act and to bide the applied sanction, to restore the rule of law and to restore the law's authority"2.

The criminal liability, in all times, was based on the committment of an offence, of a prohibited act. The criminal liability, being linked by the conception which people had about the notion of offence, it normally carried the print of the meaning given to this notion.

The way the individual behaves is reported to the freedom in thinking and acting, and the way in which the individual freedom is reflected in the committed act, either permitted, or not.

The Criminal Law incriminates the human actions which constitute an infraction/offence (lat. infractio - destruction), actions committed with guilt, provided for by the criminal law, unjustified and imputable, and also the criminal sanctions which are applied to persons who committed these actions.

To establish the actions that are going to be prohibited, the legislator starts from the observation that these actions were once committed in reality, and there is a fear that they could be repeated.

The rules and the institutions of the criminal law govern and determine the criminal rule which will be applied to the action incriminated as an offence, and the sanction as a coercion measure and a way to reeducate the perpetrator. In fact, the basic institutions of the criminal law are: offence, criminal liability and criminal sanctions. Among these three institutions there is a close link and interdependence in the sence that the offence generates the criminal liability which manifests itself by applying a criminal sanction.

The offence, as provided for by the Criminal code in paragraph 2 of the Article 15, represents the only ground for criminal liability, being appreciated in the doctrine as "the headstone" of any system of criminal law.

It is the one which determines the other two fundamental institutions of the criminal law, the criminal liability and the criminal sanctions.

The institution of the offence is consecrated in Title II of the Criminal Code's General Part, being structured in 5 Chapters:

- Chapter I. General provisions

- Chapter II. Justifying causes

- Chapter III. Non-imputability (imputable character) causes

- Chapter IV. Attempt

- Chapter V. Unity and plurality of offences

- Chapter VI. Author and participants

The institution of the criminal liability is governed by expres provisions:

- in Article 15 paragraph 2 according to which an offence is the only ground for crimiinal liability;

- by the dispositions provided for by Title VII of the Criminal code's General Part where the causes, that remove criminal liability, are.

The institution of the criminal sanctions presents the characteristic that is formed of three categories of sanctions:

- Punishments

- Educative measures

- Safety measures

A criminal rule is usually followed by the majority of the recipients who adopt the conduct provided for by the criminal law.

However, there are situations when the complying conduct of the society's members is infringed by them as a result of committing crimes which are actions or inactions whom the

\footnotetext{
${ }^{2}$ C. Bulai, Criminal law (Drept penal), Volume III, pages 14-17.
} 


\section{R. Popoviciu}

criminal rule incriminates as offences. This constitutes the condition of the appearance of the criminal law relation.

In conclusion, the criminal relation is the link which arises between the state and the perpetrator as a result of having committed an action provided for by the criminal law, within existing correlative rights and obligations consisting in the applying and biding the criminal sanctions in order to defend Romania and its rule of law ${ }^{3}$.

In the Criminal code in force, the notion of the offence, in general, has received, in the content of the criminal ruule (Article 15), a precise statement in which the material, social, human, moral and judicial aspects of the offence is reflected.

The disposition of Article 15 provides that the offence is "the deed stipulated by the criminal law committed with guilt, unjustified and imputable to the person who committed it".

In the most general sense of the term, the offence is a deed of the human, an act his exterior conduct, prohibited by the law under a specific, repressive sanction, which is the punishment ${ }^{4}$.

As regarding the judicial concept of the offence, the Romanian criminal law defines it both from the point of view of the theoreticians and doctrinaires, and from the point of view of the legislator because the systematic and scientific regulations of the relations of social defence cannot be reduced to the elaboration of the special criminal rules which provide the prohibited deeds as offences and appropriate sanctions.

The offence that was commited represents the typical form of the offence described by the criminal rule.

In certain conditions, there are incriminated even the actions that reached the stage of committing the offence, and in some very special cases even those that are preparing the offence ${ }^{5}$.

Sometimes, the material activity in execution is stopped or the consequence or the desired result does not occur, for reasons beyond the pepetrator's will.

It is certain that the human activity, to have the quality of an offence, should be expressed objectively (physically), real by the execution or abstention (omission) from the execution of what criminal rule imposes ${ }^{6}$.

Human conduct, under a subjective aspect, represents the support of the way of thought, decision and execution of the criminal objective deed, being at the base of its actual commission, involving the adoption of an individual attitude of the perpetrator towards the deed and its result manifesting social peril ${ }^{7}$.

Pursuant to the exterior manifestation of the perpetrator by committing the offence, the criminal liability appears, the most severe form of the judicial liability, because through the offence as a negative action, the most important social values are broken.

The Criminal code in force stipulates in paragraph 2 of the Article 15 the principle that "offences are the only grounds for criminal liability."

So, criminal liability constitutes the immediate judicial consequence of committing an offence; only the person who committed an offence will be accountable for his/her action (the personality principle of criminal liability).

This consequence falls, under the law, on the perpetrator right at the moment of committing the deed, and not from the moment when he/she is actually held accountable for his/her action.

\footnotetext{
${ }^{3}$ M. Basarab, Criminal law. General part (Drept penal. Partea generală), Volume I, Bucharest, Lumina Lex Publishing House, 1997, page 34.

${ }^{4}$ A. Boroi, Criminal law. General part. According to the New Criminal Code (Drept penal. Partea generală. Conform Noului Cod penal), Bucharest, C. H. Beck Publishing House, 2010, page 99.

${ }^{5}$ L. R. Popoviciu, Criminal Law. General part (Drept penal. Partea generală), Bucharest, Pro Universitaria Publishing House, 2011, page 25.

${ }^{6}$ I. Tănăsescu, C. Tănăsescu, G. Tănăsescu, General criminal law (Drept penal general), Bucharest, All Beck Publishing House, 2002, page 151.

${ }^{7}$ I. Tănăsescu, C. Tănăsescu, G. Tănăsescu, quoted work, page 160.
} 
The offence is the cause of the criminal liability, and the resort to sanctions of criminal law (punishment or safety measure) is a consequence of the criminal liability.

The criminal sanction, representing the only form of sanctioning offences, accomplishes the social reformation of the perpetrator and it maintains the social order by the force of the law.

The concept of criminal liability, in as far as it relates to the achievement of the order of the criminal law only by coercion, it refers, firstly, to the situation, when the rule is not respected by the individual will, the commission of the offence represents an opposition to the legislator's will, having as consequence the criminal liability of the perpetrator and his/her sanctioning ${ }^{8}$.

The liability, in general, appears as a social fact representing the society's reaction towards an action or inaction considered at the place and time of its commission to be condemnable?.

The reaction of the society towards an action being different in relation to the place and time of its commission, the liability has a historic character and a local particularity, but, beyond all these particularities, there are elemets of continuity deriving from the universality of some socialvalues protected by social rules and the character of the broken social rules ${ }^{10}$.

Liability is not specific exclusively to the positive law, but, regardless of the form in which it manifests itself, it has at its basis an obligation - a duty to be accountable for the consequences of breaking a social rule of conduct ${ }^{11}$.

Usually, society's members conform themselves willingly to the conduct expected by the rules of the criminal law.

There are also some persons who does not comply themselves to the criminal law's requirements and they commit offences. In this case, achieving the order of the criminal law is possible only by coercion, by applying sanctions provided for by the broken rules to those who committed deeds prohibited by the accusatorial rules ${ }^{12}$.

Breaking the precept of the judicial rules atracts judicial liability: disciplinary, civil, administrative, criminal, and so on. sanction $^{13}$.

Judicial liability, in general, is a judicial relation of coercion whose object being the

As a judicial relation, the judicial liability represents a complex of connected rights and obligations that, according to the law, appear as a consequence of committing a crime and that constitute the framework of achieving the state's coercion, by applying judicial sanctions ${ }^{14}$. liability.

Breaking the precepts of the criminal law attracts, as a form of civil liability, the criminal

Achieving the order of the criminal law by coercion takes place in the framework of the criminal judicial relation of conflict as a consequence of committing the offence, by transforming the judicial relation of conformation that precedes it. In this judicial relation, takes place the accountability of the perpetrator, the judegement and, if the perpetrator is found guilty of committing the offence, the perpetrator's sanction, according to the law, and also the execution of the applied sanction. That is why the criminal judicial relation of conflict may also

\footnotetext{
${ }^{8}$ I. Tănăsescu, C. Tănăsescu, G. Tănăsescu, quoted work, page 635.

${ }^{9}$ M. Eliescu, Delict civil liability (Răspunderea civilă delictuală), Academiei R.S.R. Publishing House, Bucharest, 1972, page 5.

${ }^{10}$ V. Paşca, Course of criminal law. General part (Curs de drept penal. Partea generală), 2nd Edition in accordance with the modifications of the New Criminal code, Bucharest, Judicial Universe Publishing House, 2012, page 358.

${ }^{11} \mathrm{Gh}$. Mihai, Law's bases. The theory of judicial liability (Fundamentele dreptului. Teoria răspunderii juridice). C H. Beck Publishing House, Bucharest, 2006, pages 63-64, V. Paşca, quoted work, page 358.

${ }^{12}$ C. Bulai, quoted work, page 310.

${ }^{13}$ Gh. Boboş, Law's general theory (Teoria generală a dreptului), Dacia Publishing House, Cluj-Napoca, 1994, page 259.

${ }^{14}$ M. Costin, Judicial liability in the law of R.S.R. (Răspunderea juridică în dreptul R.S.R.), Dacia Publishing House, Cluj-Napoca, 1974, pages 31-32, V. Paşca, quoted work, page 358.
} 


\section{R. Popoviciu}

be called the judicial relation of criminal liability, as a way of achieving the order of the criminal law ${ }^{15}$.

The criminal liability reflects the immediate reaction of the society towards the perpetrator.

As a judicial phenomenon, it expresses the link between the criminal phenomenon and the person who realized that phenomenon, giving a content specific to the relation between the state and that person and determining the incidence of the sanction or the educative measure ${ }^{16}$.

The criminal liability, as a way of achieving the rule of law by coercion, to be more efficient, has to intervene promptly, as close as possible to the moment of committing the offence ${ }^{17}$. Thus, both special prevention and general prevention are realized, the feeling of security of the social values is created, the broken rule of law is recovered, and the trust in the law's authority is consolidated ${ }^{18}$.

When the criminal liability intervenes later, after committing the offence, its efficiency is diminished, and the resonance of the offence decreases gradually.

The promptitude in the activity of finding the perpetrators, of applying and executing the criminal sanctions, has educative valences different in relation to those who are called to account (to criminal liability).

This promptitude has a positive echo in the conscience of the public oppinion in two senses:

- first, those who were the victims of offences find a satisfaction in the promptitude in which the guilty ones have been punished,

- the potential victims see in this promptitude a strenghening of the feeling of security ${ }^{19}$.

For those inclined to commit offences, the promptitude in the activity of bringing someone to criminal account, and also the inevitability of this liability represents a strong way of discouragement.

As for the perpetrator, being during this time under the threat of criminal liability and sanction, the perpetrator could correct himself, and, thus, there is no longer needed a limitation in time of the criminal liability and its removal through prescription ${ }^{20}$.

As a form of judicial liability, the criminal liability implies, on one hand, the preexistence of an accusatorial rule which prohibits, under the criminal sanction, a certain action or inaction, and, on the other hand, it implies the commission by a person to which it falls the obligation of conformation, of prohibited deed in the conditions in which the deed is an offence ${ }^{21}$.

The criminal liability implies the commision of an illicit act. What is specific to it, in the case of the criminal liability, is that it has to be a penal illicit, an offence.

It is necessary that the deed prohibited by the criminal law to meet all the legal requirements to be an offence, because only the offence can generate the criminal liability. Article 15 paragraph 1 in the Criminal code in force with the marginal name "The essential features of the offence" provides that the offence is the deed stipulated by the criminal law committed with guilt, unjustified and imputable to the person that committed it.

Thus, i tis considered ${ }^{22}$ that, according to Article 15 paragraph 1 in the Criminal code, the offence has undoubtedly 4 eseential features, as:

a) the provision of the deed in the criminal law;

b) the commision of the deed with guilt;

\footnotetext{
${ }^{15}$ C. Bulai, B. Bulai, Handbook of Criminal law. General part (Manual de Drept penal. Partea generală), Bucharest, Judicial Universe Publishing House, 2007, page 327.

${ }^{16}$ C. Bulai, B. Bulai, quoted work, page 329.

${ }^{17}$ A. Boroi, quoted work, page 339.

${ }^{18}$ A. Boroi, quoted work, page 339.

${ }^{19}$ Idem.

${ }^{20}$ A. Boroi, quoted work, page 339.

${ }^{21}$ C. Bulai, B. Bulai, quoted work, page 329.

${ }^{22}$ G. Antoniu, Preliminary explanations of the new Criminal code (Explicatiii preliminare ale noului Cod penal), Bucharest, Judicial Universe Publishing House, 2010, pages 129-148.
} 
c) the committed deed to be unjustified;

d) the deed to be imputable to the person who committed it.

The provision of the deed in the criminal law is imposed by the principle of the incrimination lawfulness provided for in Article 1 in the Criminal code, according to which "the law provides which deeds are offences...."

Anti-juridicity, as a specific feature of the offence, was also noted by Traian Pop in his work, but this concept was not developed later in the Romanian criminal doctrine. Anti-juridicity implies that the committed deed is not allowed by the judicial order, excluding the existence of some justifying causes ${ }^{23}$.

The imputability (imputable character) must be examined from the material point of view (objective imputability), in the sense that there is a link between the deed and its author (imputauo facti) ${ }^{24}$.

In the criminal doctrine there is a distinction between guilt as an essential feature of the offence and guilt as an element of the offence's content. The guilt as an essential feature is expressed in the forms and ways provided for in Article 16 in the Criminal code and it exist sat any time when the completion of one of these way is determined, and, as an element of te offence's content, the guilt will exist only when the material element of the offence was committed with the form of guilt required by the $\operatorname{law}^{25}$.

The distinction is necessary because the existence of guilt as an essential feature of the offence does not always imply the existence of guilt as an element of the offeence's content.

Even if in our legislation is less obvious this double sense of the guilt, one related to the generic concept of the crime and the other related to its content, as provided by the law, in the common law legal systems, there are certain types of offenses for which it is not necessary to prove any kind of guilt in order to attract a criminal responsibility, that is, the so-called strict liability $^{26}$. In these cases, even if, as principle, no person has to be criminal responsible unless having a mens rea element, it should not be proved this element, but is sufficient to prove the actus reus element ${ }^{27}$.

The criminal liability is the consequence of the offence which constitutes its premises and its basis, and, in its turn, the determined liability constitutes the premises and the basis of the infliction of criminal sanctions.

In criminal matters, mediation, by Law 192/2006 on mediation and the organization of the mediator profession, as well as Article 10, letter $\mathrm{h}$ and Article 16, index 1 of the Law $202 / 2010$, which is applied in criminal cases regarding offenses in which criminal liability is removed, according to the law, by the withdrawal of the complaint, the reconciliation of parties, or conclusion of a mediation agreement, in the following offenses: hitting or other forms of violence, bodily harm, bodily harm by negligence, threat, rape $^{28}$, etc.

\footnotetext{
${ }^{23}$ V. Paşca, quoted work, page 128.

${ }^{24} \mathrm{~V}$. Paşca, quoted work, page 128 .

${ }^{25}$ C-tin Mitrache, C. Mitrache, Romanian criminal law, general part (Drept penal român, partea generală), Bucharest, Judicial Universe Publishing House, 2006, page 112.

${ }^{26}$ Within the common law systems, the term of strict liability (absolute liability) means a standard of liability encountered both in civil law and in criminal law. According to it, a person can be held responsible for the damages caused by his act, regardless of the guilt he had at the time when the offense has been committed. The strict liability standard is often applied in the field of traffic offenses and misdemeanors. For example, if exceeding the legal speed in the traffic, the defendant will be responsible regardless of whether he did or did not know about the speed limit posted on the road sign. For the judicial authority is enough to prove that the defendant drove with a speed greater than that provided on the road sign. See in this regard, L.A. Lascu, Modalităţi de comitere a crimelor date în competenţa instanţelor penale internaţionale, Hamangiu Publishing House, Bucharest, 2013, page 247.

${ }^{27}$ The strict liability standard can be determined by studying the intention that the legislature has had on the regulation of certain crimes or misdemeanors, meaning that if the legislator, intentionally, omitted to provide a certain type of mens rea for a specific offense, it is assumed that the legislature has provided the strict liability standard for such offenses. See, in this regard, C. Lee, A. Harris, Criminal Law Cases and Materials, Thomson \& West Publishing House, Berkeley, 2009, page 219-221 and 989.

28 L. D. Rath-Boşca, Resolving conflicts from the mediation point of view, in AIJJS no. 1/2013, page 167.
} 


\section{R. Popoviciu}

Due to this double link which situates the institution of criminal liability between the institution of offence and criminal law sanctions, the regulation of the criminal liability was split in the content of the Criminal code in force.

In the title referring to offence, the object of regulation is the problem if the criminal liability exists or not, inseparably linked to the problem if the offence exists or not.

The rules of this regulation refer to the causes that remove the existence of the offence, and, consequently, they exclude from the start the criminal liability.

\section{Conclusions}

The criminal liability is the consequence of the offence which constitutes its premises and its basis, and, in its turn, the determined liability constitutes the premises and the basis of the infliction of criminal sanctions.

The Criminal code in force provides in paragraph 2 of the Article 15 the principle that "offences are the only grounds for criminal liability".

Răspunderea penală constituie, deci, consecinţa juridică imediată a săvârşirii unei infracţiuni; numai cine a săvârşit o infracţiune răspunde penal (principiul personalităţii răspunderii penale).

The criminal liability constitutes the immediate judicial consequence of commiting an offence; only the person who committed an offence will be accountable for his/her action (the personality principle of criminal liability).

This consequence falls, under the law, on the perpetrator right at the moment of committing the deed, and not from the moment when he/she is actually held accountable for his/her action.

\section{Bibliography}

- L. A. Lascu, Modalităţi de comitere a crimelor date în competenţa instanţelor penale internaţionale, Hamangiu Publishing House, Bucharest, 2013;

- L. D. Rath-Boşca, Resolving conflicts from the mediation point of view, in AIJJS no. 1/2013;

- V. Paşca, Course of criminal law. General part (Curs de drept penal. Partea generală), 2nd Edition in accordance with the modifications of the New Criminal code, Bucharest, Judicial Universe Publishing House, 2012;

- L. R. Popoviciu, Criminal Law. General part (Drept penal. Partea generală), Bucharest, Pro Universitaria Publishing House, 2011;

- Boroi, Criminal law. General part. According to the New Criminal Code (Drept penal. Partea generală. Conform Noului Cod penal), Bucharest, C. H. Beck Publishing House, 2010;

- G. Antoniu, Preliminary explanations of the new Criminal code (Explicaţii preliminare ale noului Cod penal), Bucharest, Judicial Universe Publishing House, 2010;

- C. Lee, A. Harris, Criminal Law Cases and Materials, Thomson \& West Publishing House, Berkeley, 2009;

- C. Bulai, B. Bulai, Handbook of Criminal law. General part (Manual de Drept penal. Partea generală), Bucharest, Judicial Universe Publishing House, 2007;

- C-tin Mitrache, C. Mitrache, Romanian criminal law, general part (Drept penal român, partea generală), Bucharest, Judicial Universe Publishing House, 2006;

- Gh. Mihai, Law's bases. The theory of judicial liability (Fundamentele dreptului. Teoria răspunderii juridice). C H. Beck Publishing House, Bucharest, 2006;

- Tănăsescu, C. Tănăsescu, G. Tănăsescu, General criminal law (Drept penal general), Bucharest, All Beck Publishing House, 2002;

- M. Basarab, Criminal law. General part (Drept penal. Partea generală), Volume I, Bucharest, Lumina Lex Publishing House, 1997; 
- Gh. Boboş, Law's general theory (Teoria generală a dreptului), Dacia Publishing House, Cluj-Napoca, 1994;

- C. Bulai, Criminal law (Drept penal), Volume III;

- M. Costin, Judicial liability in the law of R.S.R. (Răspunderea juridică în dreptul R.S.R.), Dacia Publishing House, Cluj-Napoca, 1974;

- M. Eliescu, Delict civil liability (Răspunderea civilă delictuală), Academiei R.S.R. Publishing House, Bucharest, 1972;

- Oancea, Criminal law. General part, (Drept penal. Partea generală), Bucharest, Didactic and Pedagogic Publishing House, 1971. 